\title{
Natural Remedies of Common Human Parasites and Pathogens
}

\section{Omar M Amin*}

Parasitology Center, Scottsdale, Arizona

*Corresponding Author: Omar M Amin, Parasitology Center, Scottsdale, Arizona.

Received: July 12, 2019; Published: October 16, 2019

DOI: 10.31080/ASMI.2019.02.0401

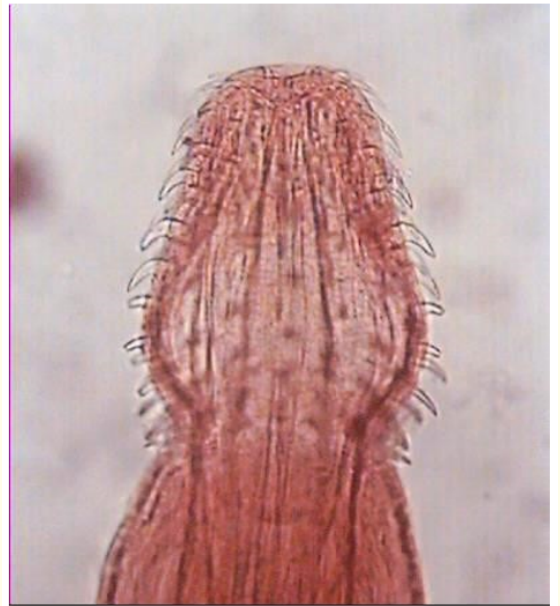

Figure 1

Diagnosis and management of:

- $\quad$ Parasitic organisms and agents of medical and public health importance in fecal, blood, skin, urine specimens.

- Toxicities related to Neurocutaneous Syndrome (NCS).

Development of anti-parasitic herbal products (F/C/R) Educational services: workshops, seminars, training and publications provided.

Consultations and protocols for herbal and allopathic treatments. Research: over 220 publications on parasites from all continents.

\section{Why test?}

You need to be tested if you have one or more of these symptoms:

\section{GI symptoms}

- Diarrhea/constipation.

- Irritable bowel

- Cramps

- $\quad$ Gas and bloating.
- $\quad$ Bleeding.

- Appetite changes.

- Malabsorption.

- Mucus.

- Rectal itching.

- Gut leakage.

- Poor digestion.

- Systemic/other symptoms

- Fatigue.

- Skin rash.

- Dry cough.

- Brain fog/memory loss.

- Lymph blockage.

- $\quad$ Allergies.

- $\quad$ Nausea.

- Muscle or joint pain.

- Dermatitis.

- Headaches.

- Insomnia.

How we get infected

1. Drinking water or juice: Giardia, Cryptosporidium.

2. Skin contact with contaminated water: Schistosomiasis, swimmers itch.

3. Food (fecal-oral infections): most protozoans, ex., Blastocysts, Entamoeba spp. and worms: Ascaris.

4. Arthropods: Lyme disease, plague, typhus, etc.

5. Air: Upper respiratory tract infections (viruses, bacteria), ex., flu, Valley fever, Hanta virus.

6. Pets: Hydatid cyst disease, heart worm, larva migrans (dogs), Toxoplasma (cats), Taenia (beef, swine.

7. People (contagious diseases): AIDS, herpes.

8. Soil: hook worms, thread worms. 


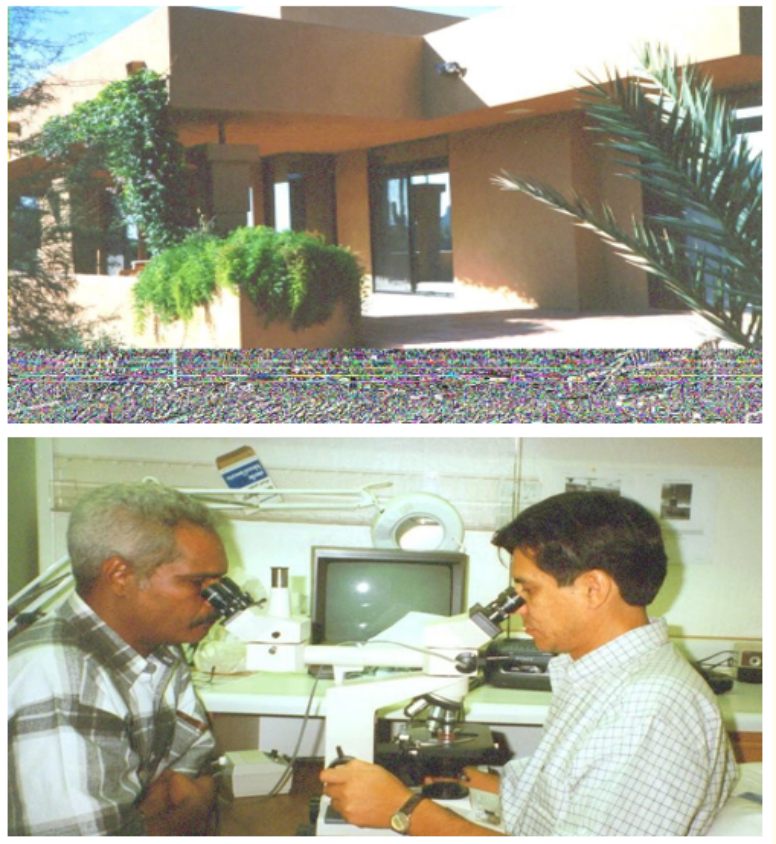

Figure 2

- $\quad$ Receiving specimens in transport vials collected in Protofix.

- $\quad$ Specimens lined up for filtration.

- Filtration process

- $\quad$ Adding the CONSED stain then the Ethyl acetate.

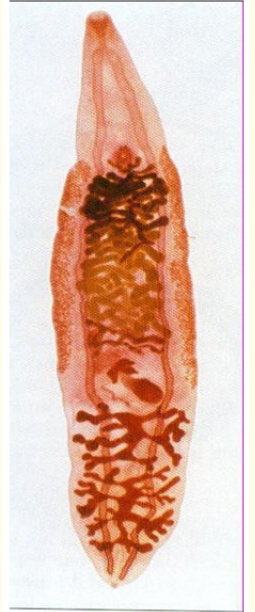

Figure 3

- Centrifugation

- $\quad$ Supernatant material decanted and debris removed Fecal plug remains at bottom.

- $\quad$ End product of a run ready for slide preparation.

- $\quad$ Creating a wet mount slide preparation for microscopic examination.
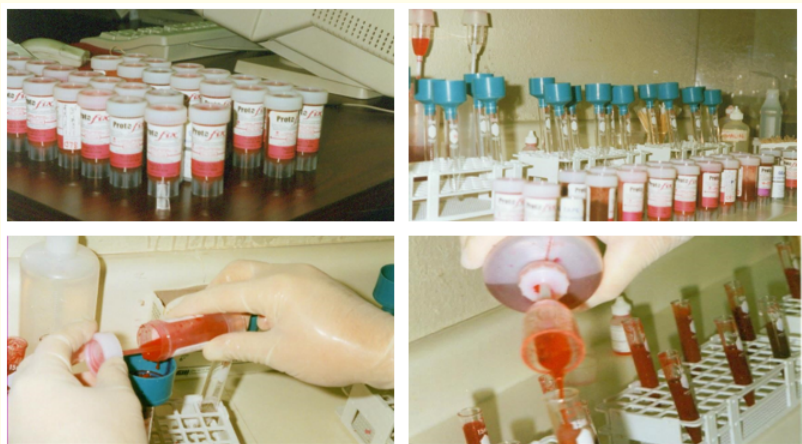

Figure 4

PCI findings of parasite presence in the USA population

- $\quad$ One third of 5,792 fecal specimens examined from patients in 48 states were infected with 19 species of parasites in the year 2000 .

- $\quad 72 \%$ of infected patients had Blastocystis hominis in single/mixed infections.

- $\quad$ Cyptosporidium parvum was the 2 nd most prevalent parasite (13\%).

- $\quad$ Entamoeba histolytica/dispar were 3rd in prevalence $(7 \%)$.

- $\quad$ Up to $31 \%$ of infections with pathogenic protozoans were subclinical.

- $\quad$ Prevalence: low (22 - 27\%) in winter but increased to $36-43 \%$ July-October.
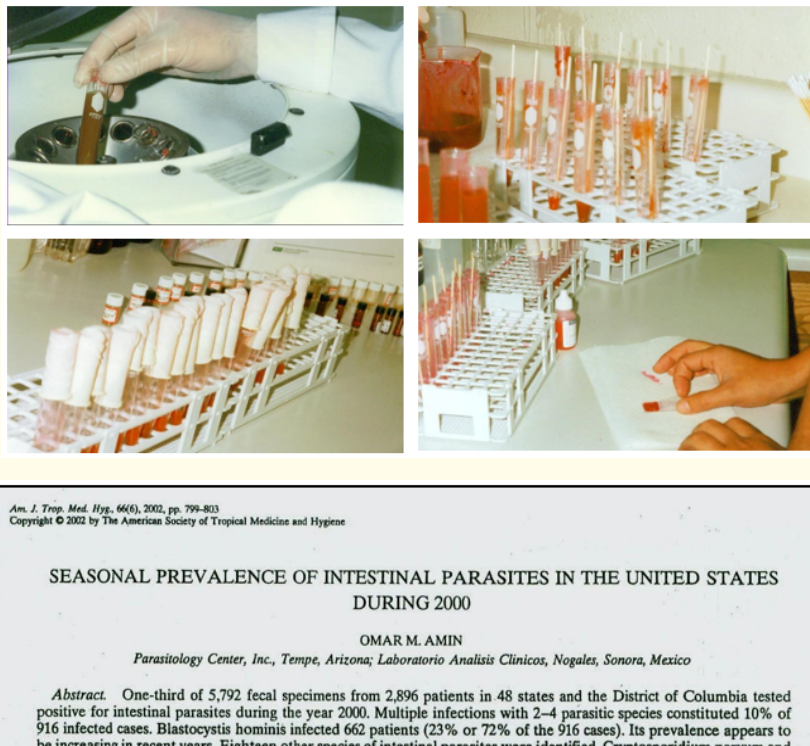

Figure 5 


\title{
The Contribution of Pathogenic Bacteria to GI Symptoms in Parasite-Fre Patients
}

\author{
Omar M. Amin \\ Parasitology Center, Inc. (PCI), 11445 E. Via Linda, \#2-419, Scottsdale, Arizona 85259, USA
}

\begin{abstract}
At the Parasitology Center, Inc. (PCl), Scottsdale, Arizona, we come across a number of patients with GI symptoms suggestive of parasitic infections that turn out to be free of parasites. Tests for pathogenic bacteria using swab culture tests showed that practically all these patients were infected with pathogenic bacteria that produce symptoms similar to those known in classical parasitic infections. Swabs from a random sample of 60 patients $(21$ males, 39 females between 2 and $87 \mathrm{yr}$ old) with overt Gl symptoms that tested negative for parasite infections during the second half of 2010 were cultured. All cultures proved to be positive for 2 or 3 of 5 species of pathogenic bacteria (Entrobacteriaceae), including, Escherechia coli (prevalence of $100 \%$ ), Klebsiella sp. $(72 \%)$, Proteus vulgaris (33\%), Citrobacter freundil $(25 \%)$, Pseudomonas aeruginosa (7\%), and 1 fungus species, Candida Sp. (5\%). Epidemiological aspects of these
\end{abstract}

Figure 6

Common remedies for parasite infections

\begin{tabular}{|c|c|}
\hline Herbal/Natural Remedies & Allopathic Remedies \\
\hline Clear/experience/harmony by Awareness Corp & Albendazole \\
\hline Protozoa, some worms & Round worms, Giardia, Microsporidia \\
\hline Tricycline by Allergy Research Group & Clindamycin and quinine \\
\hline Protozoa & Babesia bigemina and B. microti, malaria \\
\hline Biocidin and Biotonic by Biobotanical Res. Gr. & Metronidazole (flagyl) or iodoquinol \\
\hline Protozoa & Blastocystis hominis, amebiasis \\
\hline Tanalbit by Intensive Nutrition & Nitazoxanide (illinia) by Romark labs. \\
\hline Yeast & Cryptosporidium parvum, other protozoans \\
\hline Freedom/Cleanse/Restore by Parasitology Center & Mebendazole (Vermox) \\
\hline Protozoa, worms, bacteria, fungi, H. pylori, chronic & Worms (trematodes, cestodes, round worms) \\
\hline Paragone I and II by Renew Life & Praziquantel \\
\hline Parasites and Candida & Tissue invading worms and invasive amebiasis \\
\hline Unikey verma-key I and II by Unikey Hlth. Syst. & Tinidazole \\
\hline Protozoa, worms (?) & Blastocystis and other protozoans \\
\hline \multirow{2}{*}{$\begin{array}{l}\text { Natural Cleanse I, II, III by AHR, LTD, UK Protozoa, yeast, } \\
\text { fungi }\end{array}$} & Permethrin or Ivermectin \\
\hline & Skin ectoparasites and some worms \\
\hline Para-Gard by Tyler & $\underline{\text { Niclosamide }}$ \\
\hline Protozoa & Tissue invading worms \\
\hline
\end{tabular}

Table 1: 


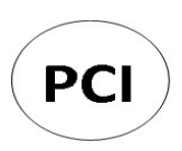

Parasitology Center Inc.

11445 E. Vin Linda, \#2-419 Scottschle, AZ 8525, USA

Av. Obregon 28-9 Nogales, Sonora, Mexic

Parasite Testing Europe LTD.

101 DURKAR LOW LANE, DURKAR, W AKEFTED, UK

\section{NATURAL REMEDIES \\ OF \\ COMMON HUMAN \\ PARASITES AND PATHOGENS}

\section{Figure 7}

Freedom/Cleanse/Restore is protected by a US patent \# 13/367629 Published Resources Used in the Formulation Of Freedom/Cleanse/Restore.

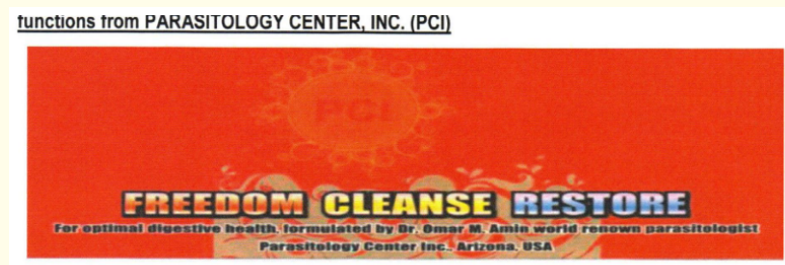

FREEDOM, CLEANSE, RESTORE

The new product includes 3 formulations, * to be taken together. It is especially designed by world renowned parasitologist Dr. Omar M. Amin for the treatment of parasites and restoration of balanced digestive functions. The formulas are based on Dr. Amin's research and experience that covers known remedies from the Ancient Egyptians and Ancient Chinese to date, and that have been published in refereed journals. For instance, see Amin, O. M. and Amin, K. O. 1998. Herbal Remedies for Parasitic Infections. Explore 8 (6): 1-59 and Amin, O. M. 2003. Ancient Egyptian Medicine. Explore 13 (5): 7-15 (reprints or PDF files available from PCI).

A good botanical remedy for the restoration of optimal digestive health is one that accomplishes 3 things: (1) defends the body from parasitic infections causing intestinal imbalance, (2) cleanses the colon from toxins and promotes regularity, and (3) supports the integrity of damaged tissues. The $3 \mathrm{PCl}$ formulas enclosed in this package accomplish those three functions, in the same order:

\section{Figure 8}

-

Dr. Omar M. Amin, MD and Ph.D. has assembled an incredible database of information regarding parasites and the herbs that attack them. This sixty page database, and other articles, are available off the Parasitology Center, Inc. (PCI) web site www.parasitetesting.com, click publications.
Appeared in EXPLORE Vol. 8 (6), 1998, Addendum.

- $\quad$ Covers all (about 800) herbal remedies for parasitic infections since Ancient Egypt and China to the present by parasite group and age groups.

\section{Herbal Remedies for Parasitic Infections}

CCopyright rog, by Omar. M. Amin, MD and Karim O.Amin, B.S.., USA

Figure 9

\begin{tabular}{|c|c|c|c|c|c|c|c|c|}
\hline sreches ur mekes & $\begin{array}{l}\text { GeNeKA } \\
\text { PARASTIES } \\
\end{array}$ & PKOIOZUA & $\begin{array}{l}\text { ENT. } \\
\text { Hustoetrica }\end{array}$ & $\begin{array}{l}\text { TRICHO- } \\
\text { MONAS }\end{array}$ & GARDIA & wORMs & $\begin{array}{l}\text { TREMA- } \\
\text { TODES }\end{array}$ & $\begin{array}{l}\text { SCHISI } \\
\text { som }\end{array}$ \\
\hline $\begin{array}{l}\text { entis farinosa } \\
\text { Jnicorn root }\end{array}$ & & & & & 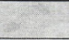 & 17 & & \\
\hline $\begin{array}{l}\text { entis spicata } \\
\text { hinese stargrass }\end{array}$ & & & & & & & & \\
\hline $\begin{array}{l}\text { eurites fordii } \\
\text { hinese wood oil }\end{array}$ & & & & & -5 & 18 & & \\
\hline langium salvifolium & - & & 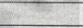 & & 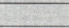 & 43 & & \\
\hline $\begin{array}{l}\text { Hiora petiolata } \\
\text { jarlic Mustard }\end{array}$ & & & $=$ & & & 11 & & \\
\hline $\begin{array}{l}\text { lium cepa } \\
\text { anion }\end{array}$ & $x^{2}$ & & -8 & & & 11,37 & & \\
\hline $\begin{array}{l}\text { lium fistulosum } \\
\text { callion }\end{array}$ & 40,18 & & & & " & 18 & & \\
\hline $\begin{array}{l}\text { lium odurum } \\
\text { :hinese }\end{array}$ & & & 27 & & - & & & \\
\hline $\begin{array}{l}\text { lium sativum } \\
\text { iarlic }\end{array}$ & $\begin{array}{c}22,37,45 \\
43,42,4\end{array}$ & 25,1 & $25,4,8$ & 25,31 & 1 & $\begin{array}{l}15,26,40 \\
25,22,37 \\
31,32,11 \\
23,41,4\end{array}$ & & \\
\hline lium scorodoprasm & & 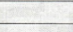 & 40 & 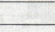 & $=$ & +2 & & \\
\hline $\begin{array}{l}\text { lium ursinum } \\
\text { vood garlic }\end{array}$ & & & $x$ & & $t^{2}$ & 11 & & \\
\hline $\begin{array}{l}\text { lium victorialis } \\
\text { erpent garlic }\end{array}$ & $=$ & & & & - & 18 & & \\
\hline $\begin{array}{l}\text { nus glutinosa } \\
\text { ommon alder }\end{array}$ & & & $x^{2}=5$ & & & 11,17 & & $=$ \\
\hline $\begin{array}{l}\text { locasia macrorrhiza } \\
\text { ireat leaved caladium }\end{array}$ & 40 & & & & & 26 & & 5 \\
\hline
\end{tabular}

O Copyright 2003 by Omar M. Amin, B.Sc, M.S., Ph.D.; USA
Abstract

The concepts of celestial medicine in Ancient Egypt are xplored with special emphasis on the ritualistic relationship between the signatures of body constitution, ailments and retween the signatures of body constitution, ailments and emedies and planetary agreement (law of similars). Medical alchemy, celestial anatomy, planetary constitution of Egyptian tisorders and herbal and other remedies are discussed. Notes m medical practice, specialties and training of physicians are zlso included. The relationship between medicine and allied tisciplines of Life as experienced in the Mystical School of Life

ntroduction

Ancient Egyptian medicine, like other aspects of Incient Egyptian civilization, was a product of the intinate relationship between the heavens and earth. The 3iogeometry of Life in its various manifestation wa only a reflection of the heavens as observed astronomially. Medicine, like architecture, engineering, religion,

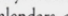
House of Life) (per ankh) is also explored. relative size, distance and angle between the three gre pyramids of Giza are identical to the scale of the thr major stars of the Orion constellation; a mirror image heavens (sec plate 2 .

In the following text I will explore how the elemen of Ancient Egyptian medicine were derived from th geometry of the heavens.

History of Celestial Medicine in Ancient Egypt

The history of Egyptian medicine began with Thot (the lbis God), Master of Writing, Numbers, Measuremen and Time (see plate A). He was later identified as Herme the Greek God founder of alchemy, astrology, univers principals of nature and orders of celestial beings, medicine, and of related sciences (see plate 3). He was als known as Idris (in Anabic). At Hermopolis, he identified th primordial eight as four couples having a single entic the initial waters and inertia (Naun and Naunet), the spart infinity (Heh and Henet), the darkness (Kek and Keket), an
Figure 10 
About Freedom/Cleanse/Restore

- $\quad$ Most efficient and popular herbal remedy for parasites in the USA.

- $\quad$ Broad spectrum: treats intestinal and tissue invading protozoan and helminth parasites as well as pathogenic bacteria, fungi, and yeast found worldwide.

- $\quad$ Acts by (1) Killing parasites and pathogens, (2) cleansing organ systems, and (3) restoring damaged tissues to a healthy state.

- With applicability for treatment of pet parasites.

- $\quad$ Available world-wide

- Ingredients synergistically combined with compatible energies.

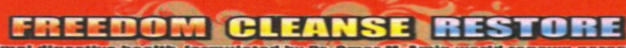

Figure 11

\section{Feed Back by Clients Who Have Used.}

\section{Feedom/Cleanse/Restore.}

I have prescribed the formulas for about 12 patients at this time.

In each case there has been eradication of numerous varieties of parasitic organisms such as Roundworm, Hookworm and amoeba.

I would recommend the formulas to others with confidence.

Dr. Anthony W. Ferro, Jr. B.S., D.C.

"I have taken the cleanse products and felt good on them. I am highly sensitive and I often have side effects from supplements and medications, and I had no problem on the cleanse. I even liked how they smelled. Within a short time.

I began to feel better. A flu like feeling that I had for a very long time was gone, and I have more energy.

Marcy Rosenthal, Tempe AZ
- My symptoms: severe burning in my intestines and bladder, chronic constipation, BLOATING, spleen enlargement, foggy thinking, insomnia from $1 \mathrm{am}$ until $5 \mathrm{am}$, muscle pain, muscle stiffness, i had stopped dreaming, bad breath, a bad odor from my lungs, fatigue. Heavy menstral bleeding ( $2 \mathrm{x}$ a month), a poor mental attitude, anxiety.

- I went to my local health store and bought a parasite cleanse. In as little as 2 days, I felt a difference. I took the product for 2 months with some success, but not a complete removal of all symptoms. I tried another parasitic supplement with little results. I had heard of Dr Omar Amin, from my naturopathic doctor. I thought he is the expert in this field, his product might be better. It was! After taking the first dose, I passed some parasites that I had never seen before. His supplements gave me my life back. I have taken his supplements full strength for 2 months and it finally seems that I am getting a grip on these free loaders. I also want to add that I tried the traditional parasitic drugs that you get prescribed from your doctor such as mebendazole and another antihemolytic with no results, it was as if they weren't even phased by the heavy duty drug!! The herbs in this supplement wreck havoc on the parasites. You will see the results, (pun intended) Follow the protocol..... After all if you don't have your health, what do you have?.

- $\quad$ Lisa McCormick

- My husband and I contacted you after a one year battle with parasites that started while spending the winter in the Florida Keys.

- $\quad$ Our symptoms began with lethargy and then gradually expanded to heart palpitations, high blood pressure, severe stomach discomfort, rumbling, gas and bloating, lower back pain and abnormal stool formations. We both would be awakened during the night with heart palpitations making sleep impossible. We found that eating meat and milk increased the symptoms so we eliminated most meat, especially pork, and switched to Lactaid. My husband had such heartburn and pressure while eating that he could not continue eating his meal. He was a very active, healthy 6'1" $185 \mathrm{lbs}$. and is now $160 \mathrm{lbs}$. One year later, after eating oranges and fresh pineapple, my husband saw a moving $1 / 2$ inch C-shaped parasite in his stool. We were so excited to finally have a sample to bring to our physician. Unbelievably, as with all the previous samples, our lab results were negative! That is when we called you, deciding to forgo the testing, and start treatment. We ordered the FCR and our symptoms began to lessen almost immediately. We faithfully took the FCR as recommended and were finally able to sleep through the night. About two months after completing the treatment, a few symptoms started to reappear and we im- 
mediately ordered a second round of FCR. One year later, we are almost symptom free.

- Gratefully,

Mark and Karen Kline.

Message: Dear Dr Amin, Before using your product, I had problems with parasites for around two years. Other products on the market helped but were not totally clearing up the problem.

After 6 weeks on your parasite cleanse, there has been the beginnings of a big improvement. I was troubled by a continual bladder infection that was caused by parasites. I didn't realize that it was the parasites causing this until I started using your product. What the other products on the market out there couldn't do, yours did I will continue on your cleans and do whatever it takes to get free from this disastrous situation. Thank you so much for all your hard work and for any trials that I can imagine that you might have gone through to make this product and get it on the market. I am eternally grateful to you, a wonderful person who has dedicated his life to help humanity in such a compassionate way.

May many, many blessing return to you.

Ellen

\section{Happy New Year!!! \$}

I am so thankful to God for leading me to Dr. Amin! I have had a chronic and systemic infection for 12 years. I have had 23 retinal surgeries (both eyes), a brain tumor removed from my brain stem and my entire lower mandible and lower teeth removed. All due to this systemic bacterial and parasitic infection. My body was in horrible condition. I had brain fog, muscle and joint pain, sore throat, loss of hair, swelling in eyes, neck pain, bad breath, diarrhea and inflammation everywhere in my body. I also had 2 more tumors that the doctors were watching.

After 3 months on Dr. Amin's product Freedom Cleanse Restore I could tell my body was starting to feel better. As the months went by I felt my body healing! After $11 / 2$ years on Dr. Amin's FCR my other 2 tumors are GONE!!!! My retinas have stopped tearing and swelling!!!! My body head to toe is healing! Thank you Dr. Amin! Thank you Karim and staff!!! You are a blessing to us all! Susan
Parasites Successfully Treated By F/C/R Blastocystis hominis (species complex) Infections caused by fecal-oral contamination and cause typical GI and extraintestinal symptoms including skin abnormalities.

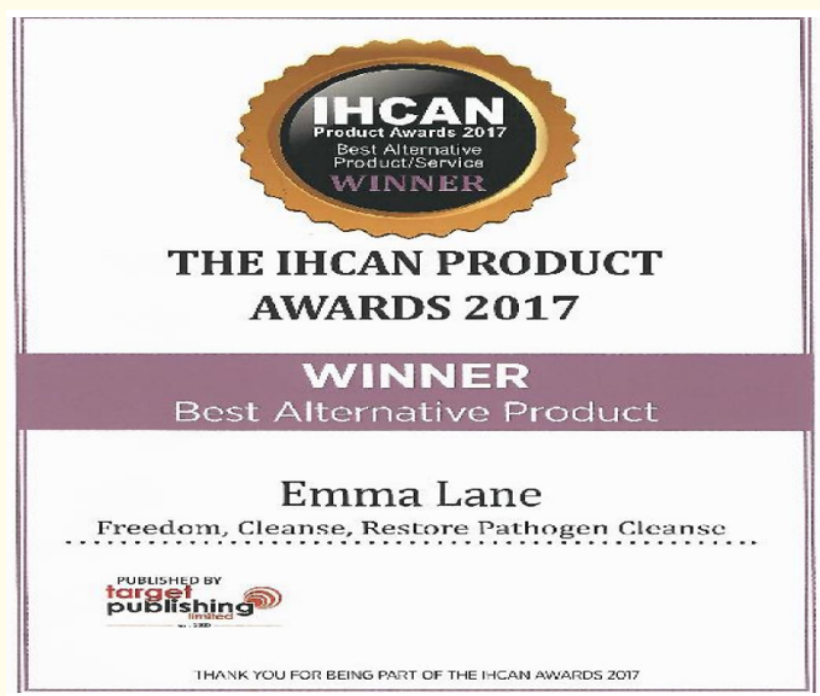

Figure 12

Parasites successfully treated by FCR Blastocystis hominis
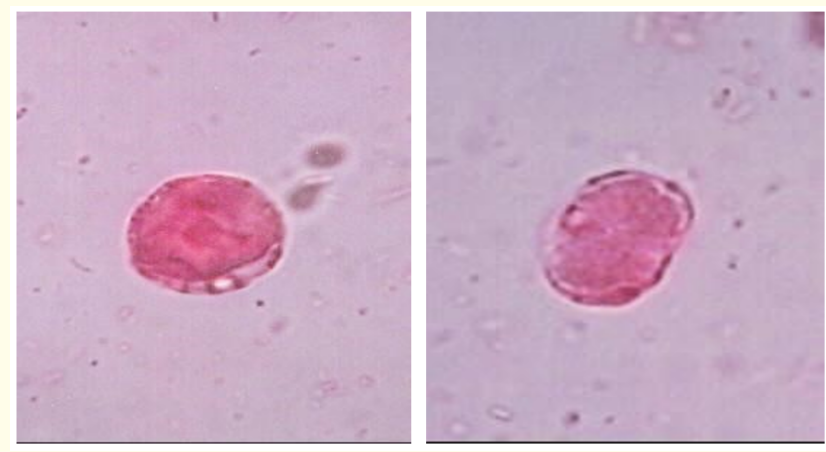

Figure 13

\section{Cryptosporidium parvum}

An under-diagnosed water-borne infection common throughout the US 


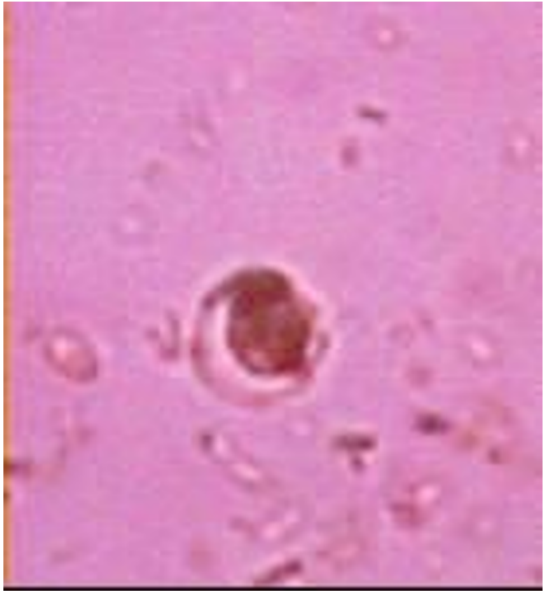

Figure 14

Best known for the 1993

- Milwaukee epidemic infecting 400,000 cases, 4000 hospitalized and over 100 deaths.

Detected in $27 \%$ of drinking water samples in households supplied by 66 surface water treatment plants in 14 states.

- $\quad$ Our prevalence rate (13\%) is higher than the $0.6-4.3 \%$ reported from North America and 2-4\% from Europe.

ISS

O 2006 Academic Journals Inc., USA

The Epidemiology of Blastocystis hominis in the United States Omar M. Amin

Parasitology Center, Inc. (PCI); 903 South Rural Rd \# 101-318, Tempe, Arizona 85281, USA

Abstract: This is the first large scale investigation of the epideniology of Blastocystis hominis in the United States. Trends in annual, seasonal, geographical and host distribution and symptomology by age, sex and season are reported in 48 states and the District of Columbia in 2002-2004. Sixteen percent of 10,582 fecal specimens from 5,291 patients tested positive. Annual prevalence rate declined from $23 \%$ in 2000 to $11 \%$ in 2004 . Infections were most prevalent in September and October and in coastal states. About one fifth of the infections were concurrent with 10 other parasitic species the most common of which was Cryptosporidium parvum. Females submitted about twice as many specimens as males and were markedly more frequently infected at the 40-49 years age oroup. Children (age 0-9 years) were the least frequently infected but the prevalence rate in male and feren children was 15 and $6 \%$ respective children was is and symptomatic with highest frequency of symptoms observed between July and September. Intestinal symptoms were considerably more common than extra-intestinal symptoms especially in females. Diarrhea and fatigue were the most common symptoms in both
male and females.
Parasitologists United Journal (PUJ)

$$
\text { Vol. 1, No. 1, January, } 2008
$$

The Epidemiology of Cryptosporidium parvum Infections in the United States

Omar M. Amin

Parasitology Center, Inc. (PCI)

Received: August, 2007 Accepted: September, 2007

Abstract

Six percent of 9,856 fecal specimens from 4,928 patients from all states and the District of Columbia tested positive for Cryptosporidium parvum infections in 2003-2005. Annual prevalence rate was similar in all three years. Overall infected than females. Additional peaks were observed in Seperecially in males that were relatively more frequently increased with age in both sexes up to age 80-89. Twenty two percent of infected patients were asymptomatic. Intestinal symptoms were relatively more common than extra-intestinal symptoms. Singly infected males $(82 \%)$ and one or more of 19 extra-intestinal symptoms (most frequently fatigue, brain fog and neurological problems).

Figure 16

\section{Entamoeba histolytica}

Entamoeba histolytica/dispar The pathogenic (Montezuma's revenge)/non-pathogenic amoebas; the third most common protozoan $(7 \%)$ in the United States. Cyst (transmission stage) Trophozoite (feeding stage).
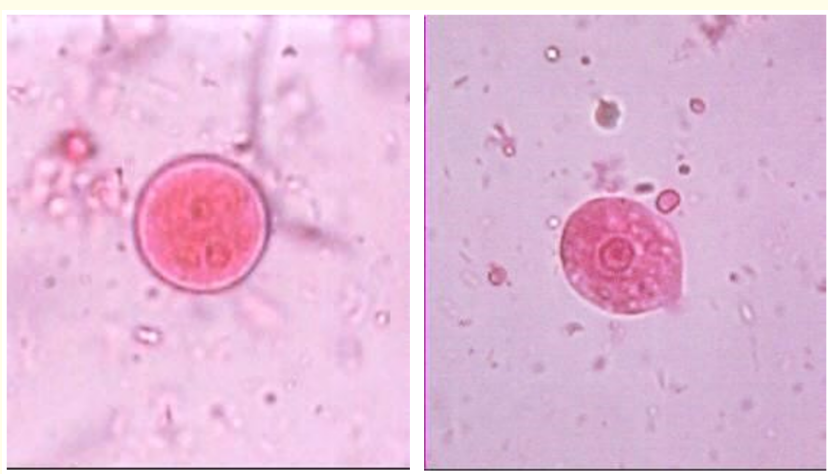

Figure 17

- $\quad$ Flask shaped intestinal ulcers from invasive trophozoites spreading and multiplying at the margins.

- $\quad$ Section in the colon mucosa showing flask-shaped ulceration site.

\section{Figure 14}




\section{Entamoeba histolytica}

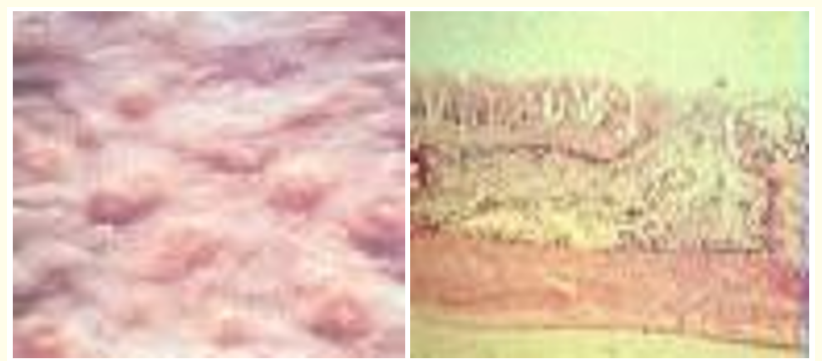

Figure 18

\section{Invasive Entamoeba histolytica trophozoites}

- Rectal muco-cutaneous amoebiasis in a child from Mexico (left).

- Ulcerative amoebic colitis with inflammation and secondary bacterial infection; from autopsy material (right).
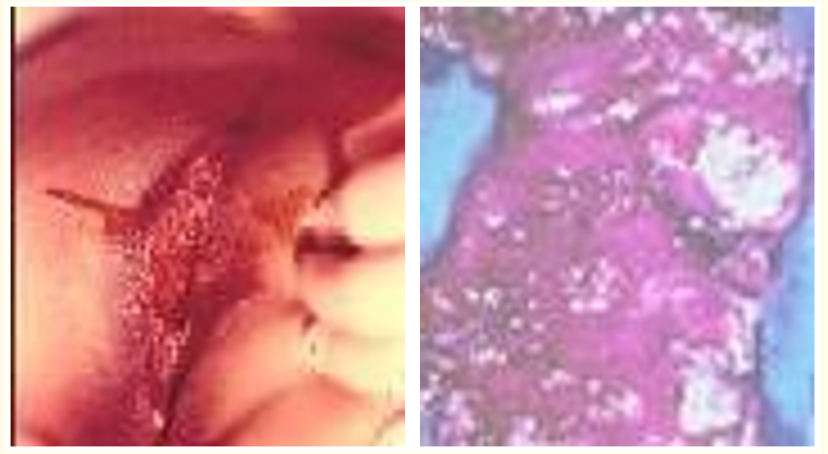

Figure 19

- Invasion of lymph vessels and cerebrum through gut wall (top right).

- Trophozoites migrate intoto to the liver causing hepatomegaly (left).

- $\quad$ Liver abscess in a 2.5 yr old Mexican child shown on left (lower right).
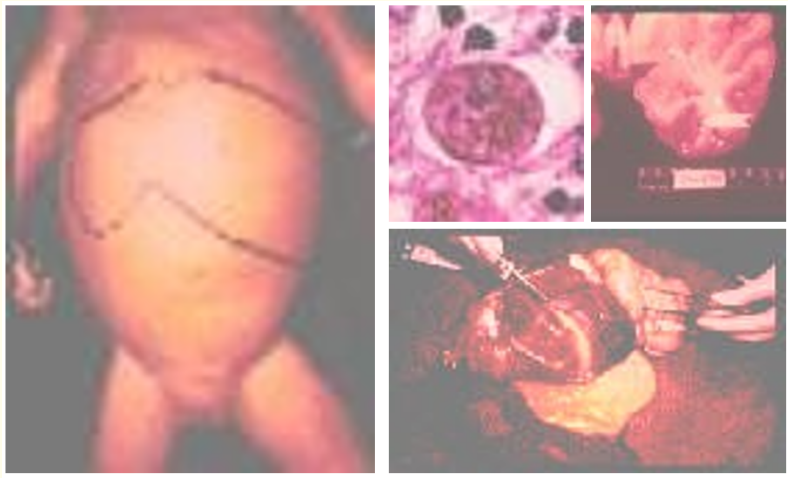

Figure 20
Giardia lamblia

- A common but under-reported intestinal parasite in the USA; hard to detect because of its adhesion to gut mucosa with a ventral sucker.

- $\quad$ Trophozoites (left) cause severe GI symptoms including malabsorption of food as well as of medications.

- $\quad$ Cysts (right) are transmitted via water (including tap water) vegetables or fruits washed in contaminated water. Carriers are important in the cycle.

- Drinking water in over $20 \%$ of households supplied by surface water treatment plants were found contaminated with Giardia cysts.
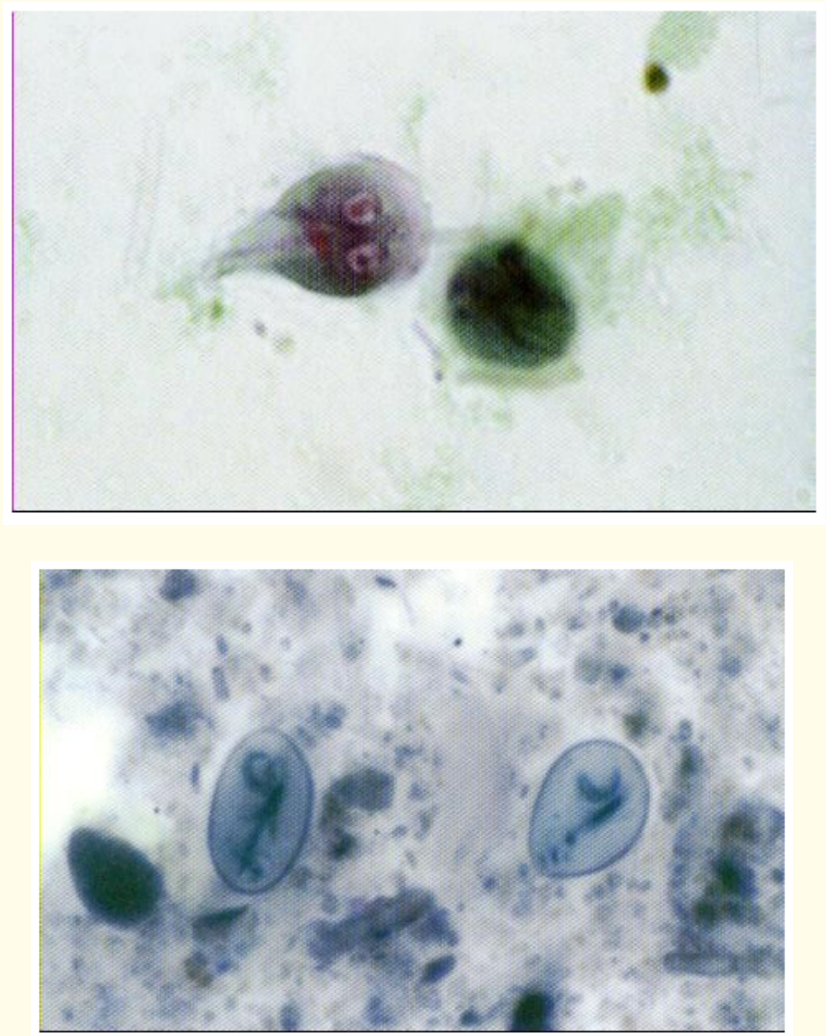

Figure 21

Helminths (Worms): Nematoda (Round Worms)

Ascaris lumbricoides

The most common worm parasite in the USA. Fecal-oral contamination brings eggs into the oral cavity of a new case. Adults reach 1 foot long. 


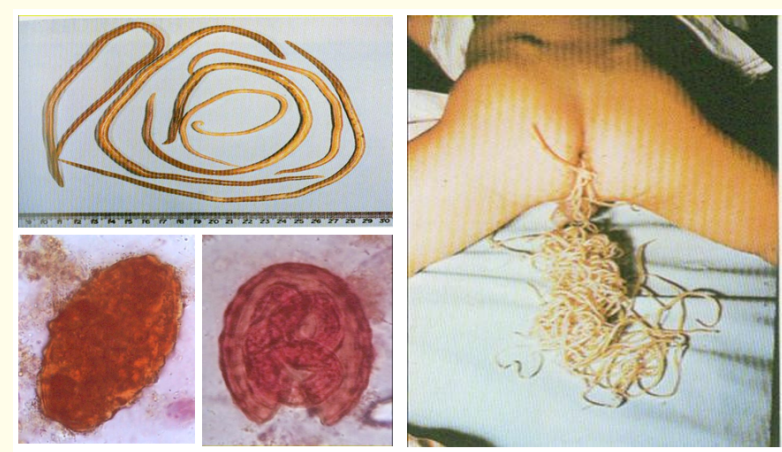

Figure 22

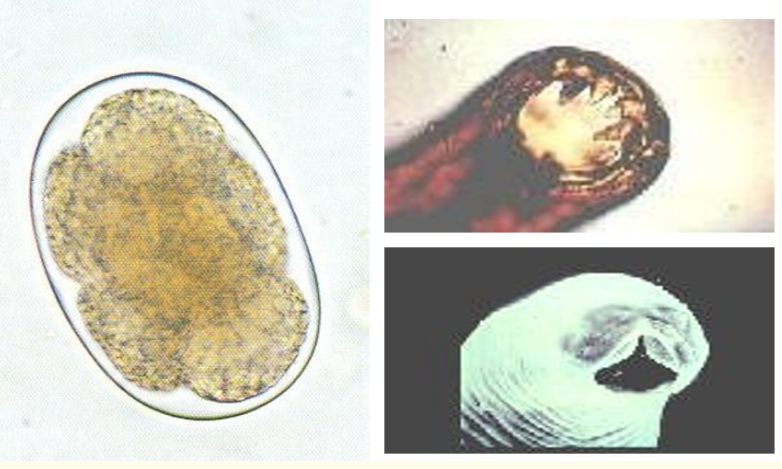

Figure 24
Nematoda (Round Worms) Ascaris lumbricoides

The ingested egg excysts and the larvae penetrate the gut wall (leakage) - blood vessels - lungs (eosinophilia, pneumonitis) bronchioles - oral cavity - reswallowed - adults in gut. May penetrate gut wall to body cavity (peritonitis).
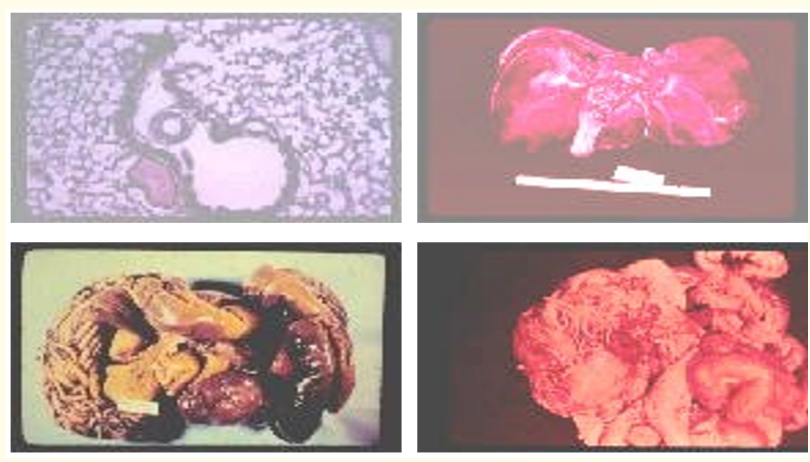

Figure 23

\section{Nematoda (Hook Worms)}

Ancylostoma duodenale and Necator Americana Have insatiable appetite for blood (RBC/oxygen) as adults. Larva penetrates skin - blood circulatory system - lungs - coughed - swallowed adult in gut.
Nematoda (Spiral Threadworms) Trichinella spiralis

A cosmopolitan parasite of carnivores involving rodents. Infects humans consuming pork/pork products having infective larvae in muscle tissue. In humans: ingested larvae - adults in gut - larvae migrate to muscles causing sub-orbital edema, sub-ingual splinter, diaphram/breathing difficulties, etc.
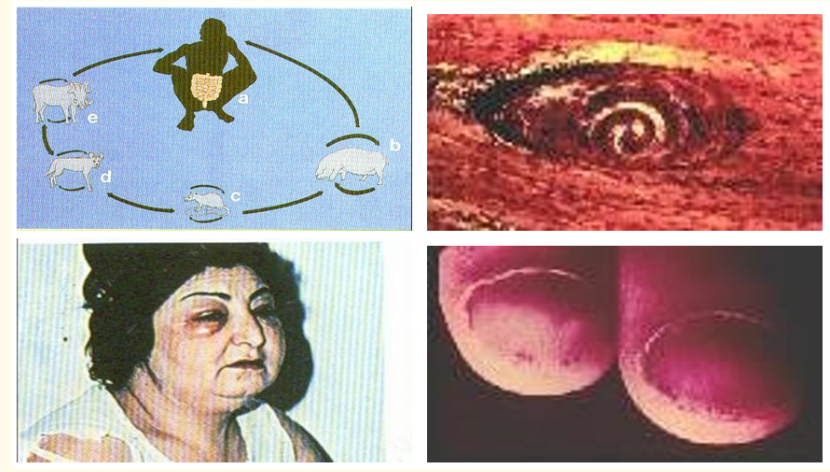

Figure 25

Nematoda (Pinworms) Enterobius vermicularis

Infects the very young and the very old via fecal - oral contamination directly or indirectly. Eggs are laid at anal orifice, diagnosis 
with Scotch tape method. Worms in the appendix have uncertain relationship with acute appendicitis.
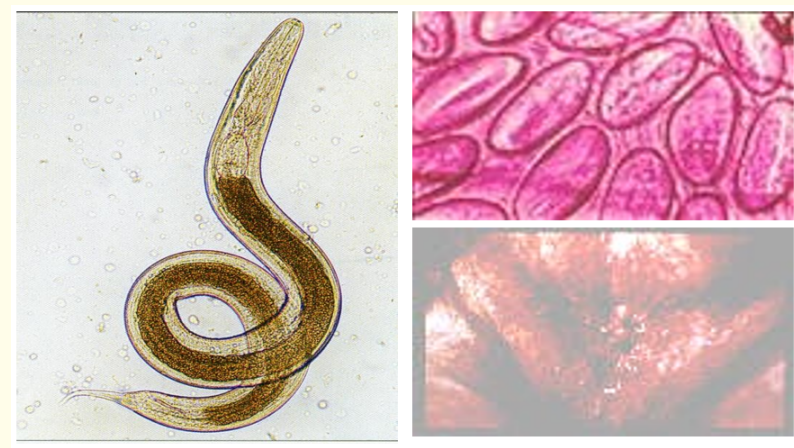

Figure 26

\section{Cestoda (Tapeworms)}

Diphyllobothrium latum (broad fish tapeworm)

Larvae in aquatic crustaceans develop to immatures (plerocercoides) in fish - ingested - up to 30 foot long adults in human intestine. Depletes vit. B12 - loss of memory and CNS functions. Very high prolific rate in a life span of 10 years + .

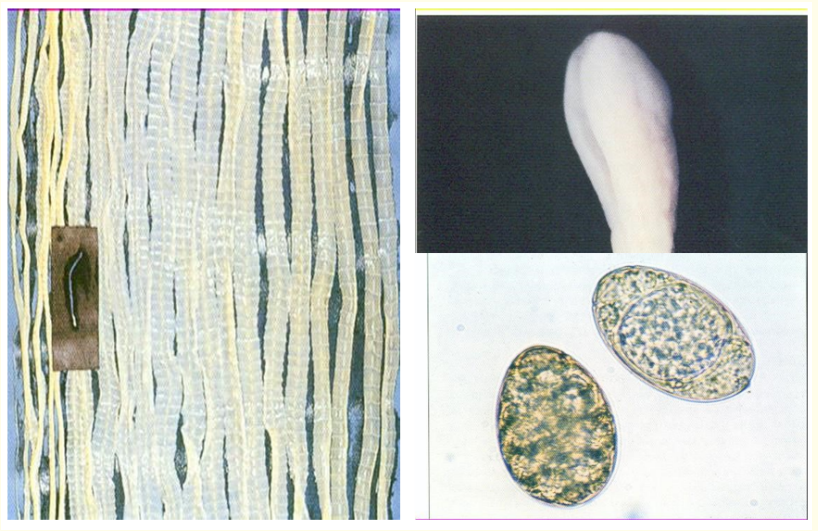

Figure 27

\section{Cestoda (Tapeworms) Taenia solium}

Taenia solium (pork tapeworm) (top left) As in the beef tapeworm Taeniarhynchus saginatus (top right), adults live in the human intestine - eggs (lower right) in mobile segments - ground
- eaten by swine/beef - hatch in gut- larvae migrate to animal muscles - eaten by man - adults. If eggs are freed in upper intestine - cysticercosis in human tissues.
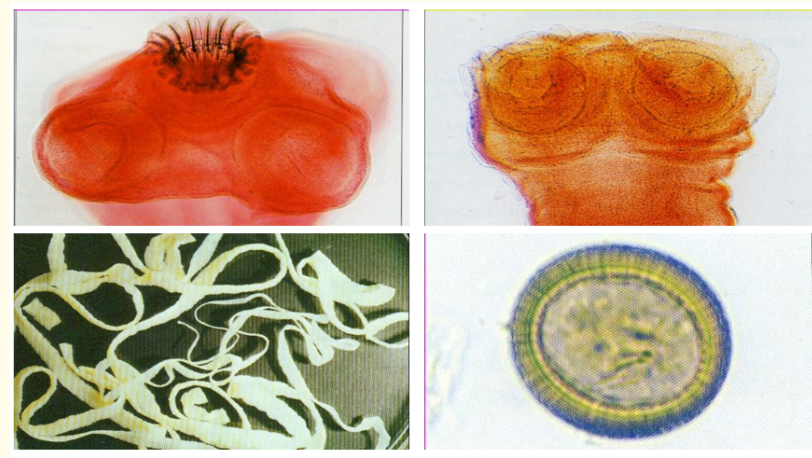

Figure 28

Trematoda (Flukes)

Fasciola hepatica and F. gigantica (liver flukes)

Infection with these flukes is cosmopolitan in liver of herbivores that graze in wet pasturage where the snail intermediate hosts are found. Man is infected by eating wild watercress on which metacercariae have encysted. Adults in liver.

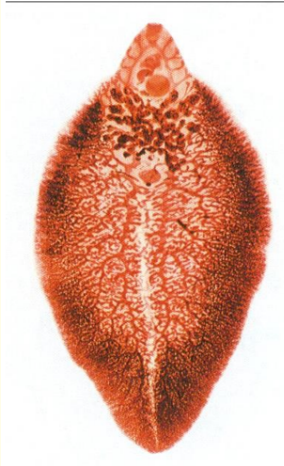

$\rightarrow$

Figure 29

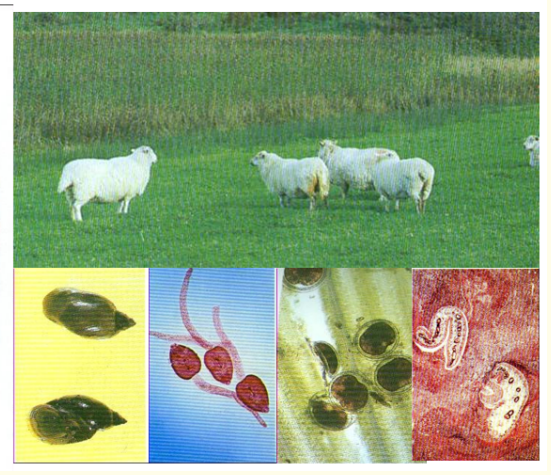

\section{Other Pathogens Successfully Treated By Freedom/Cleanse/ Restore}

- $\quad$ Fungi: Yeast, Candida, Geotrichum, Kloeckeri

- Pathogenic Bacteria: Salmonella Escherichia Coli Citrobacter Freundii H. Pylori Klebsiella, Campylobacter, Clostridium Difficile, Proteus Vulgaris Shigella, Yersinia Spp. 
The only European distributor of PCI Inc. tests and products.

For more information and to order tests or products please visit our website www.parasitetesting.co.uk.

Alternatively please email us at enquiries@parasitetesting. co.uk or by phone on 0044 (0) 2033756227

Parasite Testing Ltd Broadlands Farm, 101 Durkar Low Lane, Durkar, Wakefield, West Yorkshire, United Kingdom, WF4 3BJ, Natural Remedies, Of, Common Human, Parasites And Pathogens, This Presentation Was A Contribution Of Parasitology Center, Inc. Scottsdale, Arizona.

Volume 2 Issue 11 November 2019

(C) All rights are reserved by Omar M Amin. 